\title{
PEDAGOGICAL GRAMMAR AS THE FRAMEWORK OF TEFL RESEARCH. PART 6. NATIVE LANGUAGE SYNTAX ACQUISITION: YES-NO- AND WH-QUESTIONS
}

\section{Chernovaty L.M., Doctor of Sciences (Kharkiv)}

The paper presents the results of the experimental data analysis in the said sphere, as well as the list of the researched syntactic structures. Basing upon a high degree of the data similarity, the author makes a conclusion that the native language (English) syntax acquisition is a rule-governed process, which might be based upon the operation of language universals. Taking into account the said data, the author also offers some assumptions concerning the existence of a universal sequenceof stages in the process of yes-no- and wh-questions acquisition in English as a native language, as well as regarding the different acquisition models related to different types of wh-questions. The author considers the reasons for the absence of fully inverted structures at the first three stages of the said acquisition within the framework of maturational theories. He also shows the limitations concerning their capability to explain some phenomena observed in real child speech. The paper demonstrates that the child's speech may simultaneously contain inverted and noninverted structures of wh-questions and offers its interpretation of this phenomenon. The author examines the possible reasons for the double marking of the auxiliary (link) verb and the grammar tense of the lexical verb. The paper also analyses the role and specifics of copying and erasing operations in generating the wh-questions structures. The author shows the limitations of linguistic rules in the verification of hypotheses concerning the operations that presumably take place in the child's brain during the said generation. The paper outlines the prospects of further research concerning the development of pedagogical grammar, taking into account the abovementioned conclusions.

Key words: copying, double marking, erasing, native language acquisition, stages of acquisition, syntax acquisition, universal grammar, wh-questions, yes-noquestions.

Черноватий Л.М. Педагогічна граматика як фреймове поняття для досліджень у галузі методики навчання іноземних мов. Частина 6. Засвосння синтаксису рідної мови: загальні та спеціальні запитання. Ця стаття $є$ шостою в циклі присвячених педагогічній граматиці публікацій. У розвідці наведено результати аналізу даних досліджень у згаданій сфері, а

(C) Chernovaty L., 2019 
також перелік досліджуваних синтаксичних структур. Виходячи 3 високого ступеня подібності таких результатів, сформульовано висновок про те, що зміст засвоєння синтаксису англійської мови як рідної грунтується на певних етапах, а також про можливу роль мовних універсалій у цьому процесі. Грунтуючись на даних аналізу, запропоновано висновки про існування універсальної послідовності етапів засвоєння структур загального та спеціального запитань у процесі оволодіння англійською мовою як рідною, а також про варіативність моделей засвоєння різних типів спеціального запитання. Узагальнено перелік операцій, на яких грунтується засвоєння спеціальних запитань. Розглянуто причини відсутності повністю інвертованих структур на перших трьох етапах згаданого засвоєння 3 точки зору матуралістичних теорій, а також показано певні їх обмеження 3 точки зору здатності пояснювати явища, що реально спостерігаються у дитячому мовленні. Показано можливість одночасної наявності інвертованих i неінвертованих структур спеціальних запитань у згаданому мовленні та запропоновано тлумачення ймовірних причин цього явища. Розглянуто можливі механізми подвійного маркування допоміжного дієслова i граматичного часу смислового дієслова. Проаналізовано місце та особливості функціонування операцій копіювання і стирання при побудові питальних структур. Показано обмеженість ролі лінгвістичних правил у процесі пояснення операцій, що відбуваються у свідомості дитини під час породження згаданих структур, оскільки немає чітко визначених принципів реально задіяних у мозку дитини. У статті наведено приклад 3 трансформаційної граматики й реально використані конструкції, наявні помилки у вживанні конструкцій пояснюються. Окреслено перспективи подальшого дослідження 3 урахуванням отриманих результатів в процесі розробки педагогічної граматики іноземної мови.

Ключові слова: етапи засвоєння, загальні запитання, засвоєння рідної мови, засвоєння синтаксису, копіювання, подвійне маркування, спеціальні запитання, стирання, універсальна граматика.

Черноватый Л.Н. Педагогическая грамматика как фреймовое понятие для исследований в области методики обучения иностранным языкам. Часть 6. Усвоение синтаксиса родного языка: общие и специальные вопросы. Это шестая статья в цикле публикаций, посвященных вопросам педагогической грамматики. В ней приводятся результаты анализа данных исследований в упомянутой сфере, а также перечень рассмотренных синтаксических структур. Исходя из высокой степени сходства таких результатов, сформулированы заключения о наличии определенных этапов процесса усвоения синтаксиса английского языка как родного, а также о возможной роли языковых универсалий в этом процессе. Основываясь на данных анализа, предложены выводы о существовании универсальной 
последовательности этапов усвоения структур общего и специального вопросов в процессе овладения английским языком как родным, а также о вариативных моделях усвоения разных типов специального вопроса. Рассмотрены причины отсутствия полностью инвертированных структур на первых трех этапах упомянутого усвоения с точки зрения матуралистических теорий, а также показаны некоторые их ограничения с точки зрения способности объяснять явления, которые реально наблюдаются на практике. Показана возможность одновременного наличия инвертированных и неинвертированных структур в детской речи и предложена интерпретация этого явления. Рассмотрены возможные причины феномена двойного маркирования вспомогательного глагола и грамматического времени смыслового глагола. Проанализированы место и особенности функционирования операций копирования и стирания при построении вопросительных структур. Показана ограниченность роли лингвистических правил в процессе объяснения операций, происходящих в сознании ребенка во время порождения упомянутых структур, что происходит из-за отсутствия четко определенных принципов, которые реально действуют в мозге ребенка. Статья содержит сравнительный пример конструкций, предложенных в трансформационной грамматике и тех, которые использованы реально, выявленные ошибки в использованных конструкциях поясняются. Очерчены перспективы дальнейшего исследования с учетом полученных результатов в процессе разработки педагогической грамматики иностранного языка.

Ключевые слова: двойное маркирование, копирование, общие вопросы, специальные вопросы, стирание, универсальная грамматика, усвоение родного языка, усвоение синтаксиса, этапы усвоения.

Introduction to the series. Numerous research in teaching foreign languages, specifically in the development of grammar competence, often seem to lack a common framework to integrate them into a single area with uniform approaches, terminology and criteria. It accounts for the current importance of the issue under consideration.

The object of this paper is the comparative aspect of the native (NLA) and foreign languages acquisition (FLA) with the subject being the characteristics of the NLA. The aim of this study is to analyse the latter with the purpose of its further comparison with the FLA. This is the sixth (see [4-8]) in a series of articles focusing on the Pedagogical Grammar (PG) issue [11; 12], where the author, basing on the research data, is planning to discuss the various aspects of the problem. 
As it was mentioned in the first article of the series [4], the development of an efficient PG should be based on an adequate FLA psycholinguistic model. Such PG has to take into account the regularities of the speech grammar mechanisms development in general and the foreign language grammar mechanisms in particular, specifically in the aspects where the NLA and FLA processes are different. In the previous papers [8], we started overviewing strategies, procedures and processes at the simple sentencestage in the NLA. In this article, we are going to review the syntax acquisition (yes-no- and wh-questions) in NLA, which would be used for the comparison with the FLA in our next papers.

Interrogative structures acquisition. Yes-no-questions. The available research (see the analysis in $[1 ; 3 ; 12 ; 16]$ ) gives ground to view it as a two-stage process. The first stage is characterized by the use of affirmative structures without any auxiliaries. The information request function is realized by means of a rising tone. The onset of the second stage is indicated by the emergence of the subject-auxiliary inversion, which contributes to the transformation of the affirmative structure into an interrogative one. Basing upon the data on the wh-questions (see further), it may be assumed that the subject-auxiliary inversion is first acquired concerning those auxiliaries that are present in the affirmative structure, while the do auxiliary is the last to emerge.

Wh-questions acquisition. This type of questions requires the availability of the full-fledged category of the auxiliary verb, as well as the acquisition of four operations: (1) subject-auxiliary inversion (This is $a$ book $\rightarrow$ Is this a book?); (2) question word movement (This is what $\rightarrow$ What is this?); (3) insertion of the auxiliary do (Do you like sports?); (4) separation of the affix from the lexical verb and its attachment to the auxiliary verb (Do + es he like(s) sports?).

Research (see the review in [3; 12; 16], as well as [2; 10; 11; 13; 14; 17]), allows to distinguish the following stages in the wh-questions acquisition process.

Stage 1. Asking wh-questions without auxiliaries (e.g. What that?).

Stage 2. Use of some auxiliaries (can, will), but without inversion (e.g. What you can do?).

Stage 3. Inversion of all auxiliaries except do (e.g. What can you do? but What you want?).

Stage 4. Fully inverted questions. 
In addition to the errors observed at stages 1-3 (see above), two more typical types of errors have been registered: (a) double marking of the grammar tense (e.g. Did you opened it?); (b) double marking of the auxiliaries (e.g. What is this is?). In the former case, the grammar tense marker, instead of being removed from the lexical verb and attached to the auxiliary one, is redundantly copied on the lexical verb. In the latter case, the auxiliary verb is redundantly copied in its former position after the inversion.

The reasons for the absence of full inversion until the final stage of the wh-questions acquisition have been discussed by a number of authors. In some research [13] it was assumed that inversion is initially acquired in yes-no questions, and only later it is transferred upon whquestions. Others [3] attempted to explain it basing on the maturational theory, i.e. by the impact of realization factors. Within this theory, it is assumed that the child possesses adult's grammar from the very beginning, but the realization factors, related to the variables in the maturation time of different rules, restrain the child's capabilities at specific stages.

In particular, the maturational theory proponents assume that as early as stage 2 , the child may possess both inversion and the questionword movement mechanisms. However, inversion does not work in whquestions because of the limitations on the number of simultaneous operations the child can perform. At this stage, the child's intuitive grammar limits his/her capabilities to one operation only. As soon as the corresponding brain area has matured, the limitation is relieved and the child starts performing two operations at a time (inversion and the question-word movement).

Though this explanation looks quite logical, it caused several problems: (a) why is it the operation of the question-word movement (and not inversion) that the child chooses under the conditions of the said limitations, i.e. why don't we observe sentences like Is the book where?; (b) the statement that inversion is initially acquired in yes-no questions, and only later is transferred upon wh-questions, contradicts findings in some experiments [12].

An attempt to relieve this contradiction was made by combining realization and competence factors. The latter are interpreted in the framework of the view that the child's errors reflect his/her grammar system being in the state of permanent restructuring [14]. According to 
this approach, the wh-questions acquisition process is relatively slow and gradual. Initially it is limited only to some question words. Specifically, those are what and where, which are generally easier, because the same question words are the primary indicators signalling the transition to the next stage in the acquisition of other structures as well.

Thus, for a certain period, the child's speech may simultaneously contain inverted yes-no-questions, inverted wh-questions with what and where, and non-inverted wh-questions with the remaining questionwords. It may be connected with a greater conceptual complexity of the means to express the adverbial modifiers of time, manner and cause (when, how, why). Some researchers [14] also assume that the fact of inversion being initially acquired in yes-noquestions might be an illusion. In their view, the presence of inversion in yes-noquestions does not necessarily mean that the corresponding rule has been acquired. The perceptual salience of the auxiliary verb in front of the subject may contribute to the acquisition of the inverted yesnoquestions as formulas. That is, the child, while using the auxiliary verb in the initial position, may not realize that it belongs to the same category as the similar verbs in affirmative sentences. Thus, the auxiliary verbs in affirmative and interrogative sentences may be acquired as two separate categories and only later be generalized and integrated into a single one. In essence, this process is the same as the one discussed in morphology acquisition [8].

This interpretation looks convincing, but it excludes the possibility of the auxiliary (link) verb double marking (i.e. sentences like Is this is a book?) in the child's speech. However, such sentences (though rarely) do happen. To solve this minor (due to a small amount of occurrences) problem, it could be assumed that the mechanism under consideration is dominant (but not the only one) in the wh-questions acquisition. In general, there are different explanations of the double marking cases, depending on the approach.

Within the framework of the maturational theory and realization factors, all actions related to the relocation of sentence elements are considered to involve two main operations: copying and erasing. Real transformations (if they do exist at all), may also involve the operations of marking and attachment; though some authors [10] limit themselves to the two abovementioned ones. The said authors assume that the Universal Grammar rules prescribe the child to perform the copying 
operation first, while the erasing operation is always the second one in the order. For example, in transforming the affirmative sentence This is a book into an interrogative one, the child copies the link verb (is) first, then performs fronting (moves it in front of the subject), and only then erases it in its former position. Within the hypothesis under consideration, it is assumed that the child has acquired the mechanism of interrogative structures formation when he/she has realized (on the subconscious level) that copying is always followed by erasing. Because the double marking errors are usually observed in a relatively late phase (between the third and the fourth stages), it naturally causes a slight bewilderment as to why it takes such a long time for the child to realize the said order of the operations [12]. The proponents of the maturational theory explain all such occurrences by the maturation time of the corresponding universals. The hypothesis under consideration also predicts the generation of sentences like What did you see what? However, such sentences have not been observed in child' speech. The theory might have been corroborated if the child generated sentences like Where did you go to the cinema? if we assume that after fronting the question word (where), the adverbial modifier of place (to the cinema), replaced by the said question word, should be erased.

In general, according to the current views [12], the verification of hypotheses by means of linguistic rules (including those of transformational grammar) should be seen rather as an acceptable variant due to the absence of a better one, than as a completely adequate procedure, because it is unknown how well those rules describe the operations actually happening in the child's brain. Compare, for example, the predictionsbythe transformational grammar (TG) concerning the order of acquisition of the following sentence structures and the real order [9].

\begin{tabular}{|l|c|c|}
\hline \multicolumn{2}{|c|}{ Sentences } & \multicolumn{2}{|c|}{ Order of acquisition } \\
\cline { 2 - 3 } & $\begin{array}{c}\text { TG } \\
\text { prediction }\end{array}$ & $\begin{array}{c}\text { Real } \\
\text { order }\end{array}$ \\
\hline (1) John was pushed by a car; (2) John was pushed & $(1) \rightarrow(2)$ & (2) $\rightarrow$ (1) \\
\hline
\end{tabular}


(1) John gave a present to Mary; (2) John gave Mary a present

$(1) \rightarrow(2)$

$(2) \rightarrow(1)$

A logical explanation of the verb’s grammar tense double marking (Did you caught it?) has been suggested by a number of authors [15], who highlight the fact that such errors are mostly related to the sentences with do and irregular verbs, irrespective of the latter's regular or overgeneralized forms (Didyou broke it? or Did you breaked it?). In the said authors' opinion, in this case we deal with the word recall errors, as those words have might been stored in the memory according to the lexical principle, alongside with other words (e.g. open, take, etc.).

The fact that the double marking error is observed exclusively (or, at least, predominantly) with the sentences containing the operator $d o$, may be explained by the specific nature of the latter, whose sole function is to mark the grammar tense. As far as the errors related to the double marking of the auxiliary verb are concerned, some authors [9] suggest ignoring them because of their low frequency.

As a kind of generalization, we can conclude that, like in the case of other aspects of the NLA, the operation of the above-mentioned principles in the acquisition of English as a foreign language could be regarded as a proof of the NLA and FLA similarity, which is the prospect of our further research.

\section{LITERATURE}

1. Черноватый Л.Н. Основы теории педагогической грамматики иностранного языка: дис. ... д-ра пед. наук: 13.00.02 / Харьковский нац. ун-т им. В.Н. Каразина. Харьков, 1999. 453 с.

2. Ambridge B., Rowland C., Theakston A., Tomasello M. Comparing different accounts of inversion errors in children's non-subject whquestions: What experimental data can tell us? Journal of Child Language, 2006. № 33. P. 519-557.

3. Brown R. A First Language: The Early Stages. Cambridge, Mass: Harvard Univ. Press, 1973. 430 p.

4. Chernovaty L.M. Pedagogical grammar as the framework of research in teaching foreign languages. Part 1. Levels and types of grammar. Викладання мов у вищих навчальних закладах освіти на сучасному 
етапі. Міжпредметні зв'язки. Х.: ХНУ ім. В.Н. Каразіна, 2016. Вип. 29. С. 157-166.

5. Chernovaty L.M. Pedagogical grammar as the framework of research in teaching foreign languages. Part 2. Native language acquisition: General background. Викладання мов у вищих навчальних закладах освіти на сучасному етапі. Міжпредметні зв'язки. Х.: ХНУ ім. В.Н. Каразіна, 2017. Вип. 30. С. 156-165.

6. Chernovaty L.M. Pedagogical grammar as the framework of TEFL research. Part 3. Native language acquisition: strategies, procedures and processes. The word-combination stage. Викладання мов у вищих навчальних закладах освіти на сучасному етапі. Міжпредметні зв'язки. Х.: ХНУ ім. В.Н. Каразіна, 2018. Вип. 31. С. 154-163.

7. Chernovaty L.M. Pedagogical grammar as the framework of TEFL research. Part 4. Foreign language acquisition: strategies, procedures and processes. Викладання мов у вищих навчальних закладах освіти на сучасному етапі. Міжпредметні зв'язки. Х.: ХНУ ім. В.Н. Каразіна, 2018. Вип. 32. С. 126-134.

8. Chernovaty L.M. Pedagogical grammar as the framework of TEFL research. Part 5. Native language acquisition: morphology acquisitionat the simple sentence stage. Викладання мов у вищих навчальних закладах освіти на сучасному етапі. Міжпредметні зв'язки. Х.: ХНУ ім. В.Н. Каразіна, 2019. Вип. 33. С. 118-126.

9. de Villiers J., de Villiers P. Language Acquisition. Cambridge, Mass.: Harvard Univ. Press, 1978. 312 p.

10. Erreich A., Valian V., Winzemer J. Aspects of a theory of language acquisition. Journal of Child Language. 1980. № 2. P. 157-179.

11. Hyeson P. When-questions in second language acquisition. Second Language Acquisition. 2000. Vol. 16. Issue 1. P. 44-76.

12. Ingram D. First Language Acquisition. Cambridge: Cambridge Univ. Press, 1992. $572 \mathrm{p}$.

13. Kuczaj S.A., Maratsos M. What children 'can' say before they 'will'. Merrill-Palmer Quarterly of Behavior and Development. 1975. № 21. P. 89-111.

14. Kuczaj S.A., Maratsos M. Initial verbs of yes-no questions: a different kind of general grammatical category. Developmental Psychology. 1983. № 19. P. 440-444. 
15. Maratsos M., Kuczaj S.A. Against the transformational account: a simpler analysis of auxiliary overmarkings. Journal of Child Language. 1978. № 5. P. 337-345.

16. Routledge Handbook of Second Language Acquisition / Gass S.M., Mackey A. (eds.). London: Routledge, 2012. 599 p.

17. Rowland C.F., Pine J.M., Lieven E.V., Theakston A.L. Determinants of acquisition order in wh-questions: re-evaluating the role of caregiver speech. Journal of Child Language. 2003. Vol. 30. Issue 3. P. 609-635.

\section{REFERENCES}

Ambridge, D., Rowland, C., Teakston, A. and Tomasello, M. (2006). Comparing different accounts of inversion errors in children's non-subject wh-questions. What experimental data can tell us? Journal of Child Language, 33, pp. 519-557 [in English].

Brown, R. (1973). A First Language: The Early Stages. Cambridge, Mass: Harvard Univ. Press [in English].

Chernovaty, L. (1999). Osnovy teorii pedagogicheskoi grammatiki inostrannogo yazyka [The Basics of the Foreign Language Pedagogical Grammar Theory]. Doctor of Sciences thesis. Kharkiv: V.N. Karazin Kharkiv National University [in Russian].

Chernovaty, L.M. (2016). Pedagogical grammar as the framework of research in teaching foreign languages. Part 1. Levels and types of grammar. Vykladannia mov u vyshchykh navchalnykh zakladakh osvity na suchasnomu etapi. Mizhpredmetni zviazky [Current teaching of languages at higher educational establishments. Interdisciplinary approach], 29, pp. 157-166 [in English].

Chernovaty, L.M. (2017). Pedagogical grammar as the framework of research in teaching foreign languages. Part 2. Native language acquisition: General background. Vykladannia mov u vyshchykh navchalnykh zakladakh osvity na suchasnomu etapi. Mizhpredmetni zviazky [Current teaching of languages at higher educational establishments. Interdisciplinary approach], 30, pp. 156-165 [in English].

Chernovaty, L.M. (2018). Pedagogical grammar as the framework of TEFL research. Part 3. Native language acquisition: strategies, procedures and processes.Theword-combinationstage. Vykladannia mov $u$ vyshchykh navchalnykh zakladakh osvity na suchasnomu etapi. Mizhpredmetni zviazky [Current teaching of languages at higher educational establishments. Interdisciplinary approach], 31, pp. 154-163 [in English]. 
Chernovaty, L.M. (2018). Pedagogical grammar as the framework of TEFL research. Part 4. Foreign language acquisition: strategies, procedures and processes. Vykladannia mov u vyshchykh navchalnykh zakladakh osvity na suchasnomu etapi. Mizhpredmetni zviazky [Current teaching of languages at higher educational establishments. Interdisciplinary approach], 32, pp. 126-134 [in English].

Chernovaty, L.M. (2019). Pedagogical grammar as the framework of TEFL research. Part 5. Native language acquisition: morphology acquisitionat the simple sentence stage. Vykladannia mov u vyshchykh navchalnykh zakladakh osvity na suchasnomu etapi. Mizhpredmetni zviazky [Current teaching of languages at higher educational establishments. Interdisciplinary approach], 33, pp. 118-126 [in English].

Gass, S.M. and Mackey, A. (Eds.). (2012). The Routledge Handbook of Second Language Acquisition. London: Routledge [in English].

de Villiers, J. and de Villiers, P. (1978) Language Acquisition. Cambridge, Mass.: Harvard Univ. Press [in English].

Erreich, A., Valian V. and Winzemer J. (1980). Aspects of a theory of language acquisition. Journal of Child Language, 2, pp. 157-179 [in English].

Hyeson, P. (2000). When-questions in second language acquisition. Second Language Acquisition. 16 (1), pp. 44-76 [in English].

Ingram, D. (1992). First Language Acquisition. Cambridge: Cambridge Univ. Press [in English].

Kuczaj, S.A. and Maratsos, M. (1975). What children 'can' say before they 'will'. Merrill-Palmer Quarterly of Behavior and Development, 21, pp. 89111 [in English].

Kuczaj, S.A. and Maratsos, M. (1983). Initial verbs of yes-no questions: a different kind of general grammatical category. Developmental Psychology, 19, pp. 440-444 [in English].

Maratsos, M. and Kuczaj, S.A. (1978). Against the transformational account: a simpler analysis of auxiliary overmarkings. Journal of Child Language, 5, pp. 337-345 [in English].

Rowland, C.F., Pine, J.M., Lieven, E.V. and Theakston, A.L. (2003). Determinants of acquisition order in wh-questions: re-evaluating the role of caregiver speech. Journal of Child Language, 30 (3), pp. 609-635 [in English]. 
Черноватий Леонід Миколайович, докт. пед. наук, професор кафедри перекладознавства імені Миколи Лукаша факультету іноземних мов Харківського національного університету імені В.Н. Каразіна (61022, Харків, майдан Свободи, 4); e-mail: leonid.chernovaty@karazin.ua; orcid: http://orcid.org/0000-0003-34119408.

Черноватый Леонид Николаевич, докт. пед. наук, профессор кафедры переводоведения имени Николая Лукаша факультета иностранных языков Харьковского национального университета имени В.Н. Каразина (61022, Харьков, площадь Свободы, 4); e-mail: leonid.chernovaty@karazin.ua; orcid: http://orcid.org/0000-0003-34119408.

Leonid Chernovaty, Doctor of Pedagogics, Professor, The School of Foreign Languages, The Department of English Translation Theory and Practice, V.N. Karazin Kharkiv National University (61022, Kharkiv, 4 Svoboda Square); e-mail: leonid.chernovaty@karazin.ua; orcid: http://orcid.org/0000-0003-3411-9408. 